\title{
PENGARUH MODEL PROBLEM BASED LEARNING TERHADAP HASIL BELAJAR DAN RASA KEINGINTAHUAN SISWA
}

\section{INFLUENCE PROBLEM BASED LEARNING MODEL OF LEARNING OUTPUT AND CURIOSITY STUDENTS}

\author{
T Prasetyo' ${ }^{1 a}$ dan K Nisa ${ }^{1}$ \\ 1 Universitas Djuanda Bogor, Indonesia \\ a Korespondensi: Teguh Prasetyo, Email: teguh@unida.ac.id \\ (Diterima: 31-03-2018; Ditelaah: 01-04-2018; Disetujui: 02-06-2018)
}

\begin{abstract}
This study aims to describe the effect of the Problem Based Learning model on the learning outputs and the curiosity of the students on the science subjects class V SDN Banjarwaru Ciawi Bogor District Bogor. Quantitative research type with nonequivalent control group design. Data collection techniques use test result, questionnaire, and observation techniques. Post-test values of result learning experiment class and control class value $t$ arithmetic $>t$ table $(2,841>1,99)$ and significance value less than $0,05(p=0,010<0,05)$. Output bahan bahan curiosity character learners $t$, count $>t$ table $(2,841>1,998)$ while the significance value less than $0.05(p=0,000<0,05)$. Result showed that there are differences between Problem Based Learning Model in experiment class compared to Convensional Model in the control class.
\end{abstract}

Keywords: Problem Based Learning, Result Learning, curiosity character, IPA.

\begin{abstract}
ABSTRAK
Tujuan penelitian ini adalah untuk mendeskripsikan hasil pengaruh model Problem Based Learning terhadap output nilai studi dan rasa keingintahuan peserta yang dididik pada edukasi IPA kelas V SD Negeri Banjarwaru Kecamatan Ciawi Kabupaten Bogor. Jenis pengkajian kuantitatif dengan desain nonequivalent control group desain. Data diambil memakai teknik tes output nilai studi, angket, dan observasi. Nilai Post-test kelas eksperimen kelas dan kontrol kelas nilai t hitung $>\mathrm{t}$ tabel $(2,841>1,99)$ dan nilai signifikansinya kurang dari $0,05(p=0,010<1,998)$. Output bahan bahan rasa ingintahu peserta yang dididik nilai t hitung $>$ t tabel $(2,841>1,998)$ sedangkan nilai signikansinya kurang dari $0,05(p=0,000<$ $0,05)$. Kesimpulan penelitian ini adalah bahwa perbedaan antara penggunaan metode Problem Based Learning pada kelas eksperimen dibandingkan dengan metode konvensional pada kelas control.
\end{abstract}

Keywords: Problem Based Learning, output studi, rasa ingin tahu, IPA.

Prasetyo, T., \& Nisa, K. (2018). Pengaruh Model Problem Based Learning terhadap Hasil Belajar dan Rasa Keingintahuan Siswa. Didaktika Tauhidi: Jurnal Pendidikan Guru Sekolah Dasar, 5(2): 83-93. 


\section{PENDAHULUAN}

Dalam memperbaiki kualitas pendidikan, pengajaran baik dikelas maupun diluar kelas merupakan tugas pendidik. Upayaupaya yang dilakukan dalam peningkatan mutu edukasi salah satunya yaitu dengan mengubah pandangan terhadap edukasi khususnya di sekolah dasar (SD) dari pengajaran yang hanya terpaku pada pendidik (teacher centered) ke arah pengajaran yang hanya terpaku pada peserta yang dididik (student centered). Pandangan ini menuntut para pendidik berinovasi dalam mengembangkan pengajaran yang menarik minat belajar peserta yang dididik memungkinkan peserta yang dididik dapat berprestasi melalui kegiatan-kegiatan nyata yang menyenangkan dan bisa membangkitkan potensi di dalam peserta yang dididik secara optimal (Wulandari, dkk., 2012). Pendidikan IPA berorientasi pada kecakapan pendidik dalam mengembangkan kecakapan berbahasa dan meningkatkan cara berfikir peserta yang dididik, menanamkan nilainilai etika, peserta yang dididik mampu dalam memecahkan masalahnya sendiri, peserta yang dididik disiapkan untuk menghadapi akibat dari Ilmu Pengetahuan dan Teknologi (IPTEK), serta pendidik mampu meningkatkan dan mengembangkan sikap keindependenan kreatif, memiliki rasa bertanggung jawab dan rasa keingintahuan yang mendalam pada peserta yang dididik.

Pada dasarnya di SD, pendidikan IPA tidak selalu kumpulan kumpulan pengetahuan yang terdiri dari fakta, konsep, ataupun prinsip akan tetapi IPA juga yaitu tentang sesuatu hal yang ditemukan. Edukasi pengajaran IPA diharapkan sebagai penunjang terhadap peserta yang dididik agar mengenal dan mengetahui fungsi bagian dari tubuhnya, mempelajari alam sekitar serta langkah perencanaan lebih lanjut dalam mengaplikasikannya di dalam kegiatan keseharian. Pemaparan tersebut sesuai dengan dikemukakan Trianto (2013), "bahwa mendefinisikan IPA merupakan suatu tumpukan teori-teori yang tersusun secara teratur, pengaplikasiannya pada umumnya di batasi oleh gejala-gejala yang terjadi di alam, kemudian muncul dan berkembang melalui cara ilmiah seperti eksperimen dan observasi serta sikap ilmiah yang tertuntun seperti rasa keingintahuan, jujur, terbuka dan sebagainya". Sebagai bagian dari mata mapel di sekolah, harapan dalam edukasi IPA yaitu agar peserta yang dididik dapat memiliki sikap yang baik, berilmu, dan berketerampilan yang unggul serta memiliki etos dalam bekerja, dapat melatih diri dalam melaksanakan pengkajian sesuai proses cara ilmiah, dan berusaha studi mengaplikasikan pengetahuan terbaiknya.

Edukasi IPA bertujuan agar peserta yang dididik memahami konsep pengetahuan alam dan keterhubunganya dengan kegiatan di alam sekitar, memiliki keterampilan proses, sikap ilmiah dan bisa mengaplikasikan berbagai pemikiran IPA dalam eksistensi sehari-hari. Namun fakta yang terjadi di lapangan, didapati ternyata pengajaran IPA adalah pengajaran yang cukup sulit. Menurut Djohar (Mulyana, 2010) bahwa: "secara umum pengajaran IPA waktu ini belum berorientasi pada proses studi, namun lebih mementingkan pada hasil studi, yakni pada pengetahuan dari seorang pendidik terhadap peserta yang dididik".

Berdasarkan pra pengkajian pada bulan Oktober 2016 kelas V-C SD Negeri Banjarwaru menghasilkan bahwa guru lebih sering memakai metode ceramah, jawab tanya, dan penugasan sedangkan peserta yang dididik hanya terpaku dari penjelasan 
guru dan buku saja. Selanjutnya, studi dokumentasi yang dilaksanakan oleh pengkaji berserupa wali kelas V-C yang ditujukan pada dokumentasi berupa rekap nilai, yaitu di hasilkan bahan bahan output nilai studi pada edukasi IPA masih rendah, hal tersebut terbukti dari output studi Ulangan tengah Semester (UTS) mapel IPA nilai-nilainya adalah 56,5 dan sebanyak $30 \%$ dari 36 peserta yang dididik hanya 11 peserta yang dididik yang sudah tuntas atau mencapai Kriteria Ketuntasan Minimal dengan acuan penilaian yang telah ditetapkan yaitu 70. Rendahnya output nilai studi peserta yang dididik disebabkan antara lain, karena masih terpaku pada buku (tesk book), peserta yang dididik kurang termotivasi dan belum menemukan rendahnya output nilai studi peserta yang dididik edukasi IPA.

Dari beberapa unsur yang menyebabkan rendahnya nilai mapel dalam edukasi IPA, pengkaji pun tertarik untuk mengatasi rendahnya serta meningkatkan rasa keingintahuan peserta yang dididik. Usia anak SD merupakan usia memiliki rasa keingintahuan yang tinggi terhadap segala sesuatu, baik itu yang ada di dalam diri mereka maupun berasal dari faktor eksternal diri mereka. Menurut Carin (Dasim, 2012) rasa "keingintahuan didefinisikan sebagai kemauan dan kepentingan seseorang dalam menemukan jawaban dari suatu pernyataan atau hal-hal yang menimbulkan keingintahuan yang mendalam". Dalam dunia pendidikan, dalam menemukan pengetahuan yang luas, edukasi rasa ingintahu mempunyai andil dan harus terus dikembangkan mulai dari usia dini. Selain pengetahuan, terdapat ranah psikomotorik dan juga ranah afektif.

Saat melakukan proses dan mengolah pengajaran di SD, rasa keingintahuan peserta yang besar ini akan sangat bermanfaat untuk peningkatkan output nilai studi yang di digunakan mengemas proses pengajaran ke dalam model pengajaran yang bisa menampung rasa keingintahuan peserta yang dididik, mengemas materi pengajaran ke dalam media pengajaran yang dapat mengarahkan rasa keingintahuan peserta yang dididik ke arah yang sesuai dengan tujuan dari pengolahan pengajaran itu sendiri. Dengan cara demikian diharapkan output nilai studi peserta yang dididik akan maksimal.

Rendahnya rasa keingintahuan peserta didik pada pendidikan IPA dikarenakan kurangnya keterlibatan peserta yang dididik secara langsung dalam proses pengajaran, hal ini di buktikan ketika interview yang dilakukan pengkaji pada beberapa peserta yang dididik terdapat masalah mengenai pembelajaran IPA di kelas. Kesulitan peserta yang dididik diantaranya teknik penyajian guru kurang menarik, materi pada bahan pengajaran IPA yang cukup banyak teori dan kurangnya praktik langsung, peserta yang dididik bersifat sebagai pendengar dan pencatat dari apa yang disampaikan. Padahal, melalui pengolahan pengajaran yang tepat dapat mengoptimalkan rasa keingintahuan peserta yang dididik maka pengetahuan yang di hasilkan akan lebih berarti dan di harapkan akan dapat mampu memaksimalkan output nilai studi peserta yang dididik.

Model Problem Based Learning (PBL) merupakan model pengajaran yang efektif untuk digunakan dalam pengajaran proses berpikir tingkat tinggi, pengajaran yang membantu serta mempermudah jalannya peserta yang dididik untuk mencari dan memproses informasi yang sudah tertanam dalam pikirannya kemudian melakukan analisa pengetahuan melalui pengamatan dan penyelidikan yang dilakukan peserta 
yang dididik mengenai dunia sosial dan lingkungan sekitarnya. Model PBL (PBL) mengharuskan peserta yang dididik untuk bisa melatih dan menyusun sendiri pengetahuannya, serta mengaplikasikan pengembangan keterampilan yang dimilikinya dalam memecahkan suatu masalah. Seperti, dengan memberikan situasi masalah autentik, peserta yang dididik akan mencapai suatu makna dari bahan materi ajar yang disiapkan pendidik melalui proses studi dan menyimpannya dalam ingatan sehingga menyuguhkan sesuatu hal mudah kepada peserta yang dididik ketika akan melakukan suatu pengamatan dan penyelidikan.

Jadi, model PBL ini menekankan strategi pengajaran yang memanfaatkan masalah di dunia yang sesunguhnya supaya peserta yang dididik studi mengenai cara bagaimana berpikir kritis dan keterampilannya dalam memecahkan suatu masalah, serta untuk mendapatkan pengetahuan dan pemikiran yang esensial dari edukasi IPA sehingga pada pengajaran ini peserta yang dididik di haruskan agar lebih aktif, dan pendidik hanya memfasilitasinya. PBL memiliki beberapa manfaat diantaranya 1) peserta yang dididik mudah mengingat dan meningkatnya pemahaman peserta yang dididik atas materi ajar, 2) meningkatkan fokus peserta yang dididik pada pengetahuan yang relevan, 3) mengindikasi peserta yang dididik agar berpikir kritis, 4) membangun kerja serupa dalam kelompok, kepemimpinan, dan keterampilan sosial, dan kecakapan studi, serta 5) dapat memotivasi peserta yang dididik (Amir, 2010).

Menurut Sudjana (2009) "output studi adalah kecakapan kecakapan yang dimiliki peserta yang dididik sesudah ia menerima pengalaman studinya. Output studi terbentuk ke dalam tiga tipe output studi, yakni pengetahuan dan pemahaman, sikap dan cita-cita, keterampilan dan kebiasaan".

Output studi merupakan perubahan perubahan yang terjadi pada diri peserta yang dididik, hal tersebut jelas melibatkan aspek kognitif, afektif, dan psikomotorik yang merupakan bagian dari hasil dari aktivitas studi. Output nilai studi pada edukasi IPA dalam pengkajian ini difokuskan hanya dua ranah dalam teori output studi yaitu pada ranah kognitif dan ranah afektif, karena output studi pendidkan IPA pada pengkajian ini kecakapan yang di hasilkan peserta yang dididik baik secara kognitif dan afektif akan mengakibatkan suatu perubahan dalam diri peserta yang dididik sesudah melaksanakan proses pengajaran dalam suatu hal berpikir seperti pengetahuannya bertambah, pemahamannya meningkat, perubahan sikap dan perilaku, dan sebagainya.

Sementara itu, rasa keingintahuan merupakan salah satu bagian dari 18 poin edukasi karakter bangsa yang di dalamnya terkandung edukasi watak, edukasi moral yang bertujuan untuk mengembangkan kecakapan peserta yang dididik untuk memberikan apa yang baik baginya dan mewujudkan kebaikan itu di dalam aktivitas kesehariannya dengan sepenuh hati.

\section{MATERI DAN METODE}

Dalam pengkajian akan digunakan jenis pengkajian Quasi Eksperimen dengan pendekatan kuantitatif. Menurut Sugiyono (2015), "bentuk desain dari jenis Quasi Eksperimen ini mempunyai control kelompok tetapi tidak dapat berfungsi sepenuhnya untuk mengontrol faktor faktor luar yang mengindikasi pelaksanaan experiment". Hal ini tersebut dikarenakan sampel dalam pengkajian ini tidak akan diambil secara acak dari populasi yang ada 
karena peserta yang dididik secara natural telah terbentuk dalam satu kelompok atau kelas. Pengkajian ini dilaksanakan di SD Negeri Banjarwaru Kecamatan Ciawi Kabupaten Bogor pada kelas V-A dan kelas V-C. Pengkajian ini telah diawali pra-survei pada bulan Oktober 2016. Pembuatan Instrument dilaksanakan bulan Januari 2017 dengan tujuan digunakan pelaksanaan pengajaran pada semester genap tahun 2016/2017.

Populasi dalam penyelidikkan ini adalah semua peserta yang dididik yang ada di kelas V SDN Banjarwaru yang terbagi menjadi 3 kelas dengan jumlah keseluruhan 108 peserta yang dididik, yang terbagi menjadi 36 peserta yang dididik di setiap kelasnya. Pada pengkajian ini, sampel yang di ambil memakai teknik simple random sampling yaitu teknik pengambilan secara acak, berguna untuk menentukan kelas mana yang akan dimanfaatkan sebagai eksperimen kelas dan kontrol kelas. Adapun kelas yang menjadi sampel pengkajian adalah kelas V-A dan kelas V-C SDN Banjarwaru tahun ajaran 2016/2017 tepatnya peserta yang dididik kelas V-A sebagai kontrol kelas yang diajar dengan memanfaatkan pendekatan konvensional dan kelas V-C sebagai eksperimen kelas yang diajar dengan memanfaatkan model PBL. Data yang digunakan oleh peneliti di peroleh dengan memakai tes, interview, dokumentasi, dan angket.

Teknik analisis data dalam pengkajian eksperimen dibagi atas dua, yaitu analisis statistik deksriptif dan analisis statistik inferensial. Setelah itu dilakukan uji prasyarat analisis dapat dipenuhi, maka hal berikutnya yaitu menguji hipotesis. Uji statistic yang digunakan adalah uji one sample t-test.
Uji hipotesis dihitung dengan memakai aplikasi SPSS.21. Adapun kriteria keputusan yang digunakan $\mathrm{H0}$ ditolak jika signifikan lebih kecil dari 0,05 dan ha diterima jika signifikan lebih besar dari 0,05. Selanjutnya, untuk mengetahui kontradiksi nilai posttets kelompok experiment dan control kelompok memakai uji independent simple t-test.

\section{HASIL DAN PEMBAHASAN}

\section{Hasil}

Penyelidikan ini dilaksanakan dalam lima kali pertemuan pada eksperimen kelas dan kontrol kelas. Pertemuan pertama pengkaji memberikan pre-test yaitu untuk mengukur kecakapan awal peserta yang dididik, pretest yang dikasihkan yaitu mengerjakan tes sebanyak 20 buah soal pada eksperimen kelas dan kontrol kelas. Pertemuan kedua, ketiga, dan keempat digunakan untuk memberikan perlakuan, tepatnya eksperimen kelas memakai model PBL sedangkan pada kontrol kelas memakai model ekspositori. Pada pertemuan kelima setelah kedua kelas tersebut dikasih perlakuan, selanjutnya dikasihkan post-test yaitu untuk mengukur kecakapan akhir peserta yang dididik setelah dikasih perlakuan, tepatnya peserta yang dididik mengerjakan soal yang serupa dengan pretest sebanyak 20 buah soal pada eksperimen kelas dan kontrol kelas, serta pemberian kuisioner sebanyak 14 pernyataan pada eksperimen kelas dan kontrol kelas.

\section{Deskripsi Bahan-bahan Pre-test Output Studi IPA Peserta yang Dididik}

Pre-test pada eksperimen kelas dan kontrol kelas dilakukan menyelesaikan soal sebanyak 20 buah. Berdasarkan nilai output nilai studi IPA awal pada eksperimen kelas 
dan kontrol kelas maka diketahui output yang disajikan di tabel 1 .

Tabel 1 Data deskriptif pre-test output studi IPA

\begin{tabular}{|c|c|c|}
\hline Statistik & Experiment & Control \\
\hline $\mathrm{N} \quad$ (jumlah & 36 & 36 \\
\hline \multicolumn{3}{|l|}{ peserta didk) } \\
\hline Jumlah nilai & 2110 & 2290 \\
\hline Rata-rata & 58,6 & 63,6 \\
\hline \multicolumn{3}{|l|}{ Nilai } \\
\hline Nilai Minimal & 40 & 45 \\
\hline Nilai & 75 & 80 \\
\hline \multicolumn{3}{|l|}{ Maksimal } \\
\hline Median & 60 & 65 \\
\hline St. Deviasi & 12,1 & 9,5 \\
\hline Varians & 146,6 & 89,44 \\
\hline
\end{tabular}

Pada Tabel 1, kita dapat mengetahui nilai pre-test pada eksperimen kelas mencapai nilai maksimal yaitu 75 dan nilai minimal yaitu 40 dengan keseluruhan nilai 2110 di hasilkan rata-rata nilai 58,6. Selanjutnya pre-test pada kontrol kelas dilakukan dengan aktivitas yang serupa dapat diketahui nilai maksimal yaitu 80 dan nilai minimal yaitu 45 dengan keseluruhan nilai 2290 di hasilkan rata-rata nilai 63,6.

Berdasarkan output pre-test pada eksperimen kelas dan kontrol kelas, maka nilai yang di hasilkan pada kelompok experiment adalah 58,6 sedangkan nilai yang di hasilkan pada kontrol kelas adalah 63,6. Selisih nilai pada eksperimen kelas dan kontrol kelas adalah 5,0. Point tersebut menyatakan bahwa kecakapan awal pada kelompok experiment dan kontrol kelas tidak jauh berbeda. Nilai tersebut jika disajikan dalam histogram dapat dilihat pada Gambar 1.

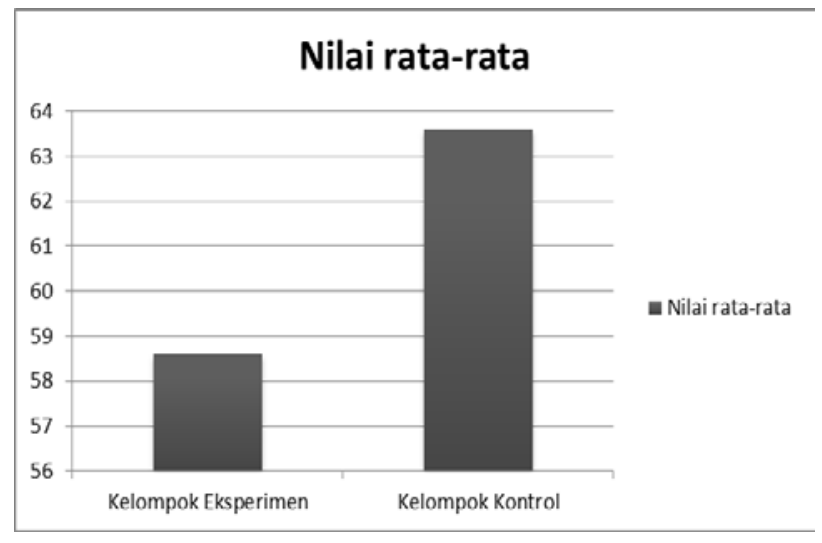

Gambar 1 Histogram perbandingan pre-test output nilai studi IPA eksperimen kelas dan kontrol kelas

\section{Deskripsi Bahan bahan Post-test Output studi IPA Peserta yang dididik}

Post-test pada eksperimen kelas dan kontrol kelas dilaksanakan kepada 36 peserta yang dididik berupa 20 buah soal yang harus diisi peserta yang dididik sesudah dikasih perlakuan, baik pada eksperimen kelas dan kontrol kelas. Berdasarkan nilai akhir output nilai studi IPA peserta yang dididik, maka diketahui output yang disajikan di tabel 2.

Tabel 2 Bahan bahan deskriptif post-test output studi IPA

\begin{tabular}{|c|c|c|}
\hline Statistic & Experiment & Control \\
\hline $\mathrm{N} \quad$ jumlah & 36 & 36 \\
\hline \multicolumn{3}{|l|}{ peserta didk) } \\
\hline Jumlah nilai & 2980 & 2800 \\
\hline Rata-rata & 82,8 & 77,8 \\
\hline \multicolumn{3}{|l|}{ Nilai } \\
\hline Nilai Minimal & 60 & 55 \\
\hline Nilai & 100 & 100 \\
\hline \multicolumn{3}{|l|}{ Maksimal } \\
\hline Median & 80 & 77,5 \\
\hline St. Deviasi & 11,6 & 11,4 \\
\hline Varians & 134,9 & 130,63 \\
\hline
\end{tabular}




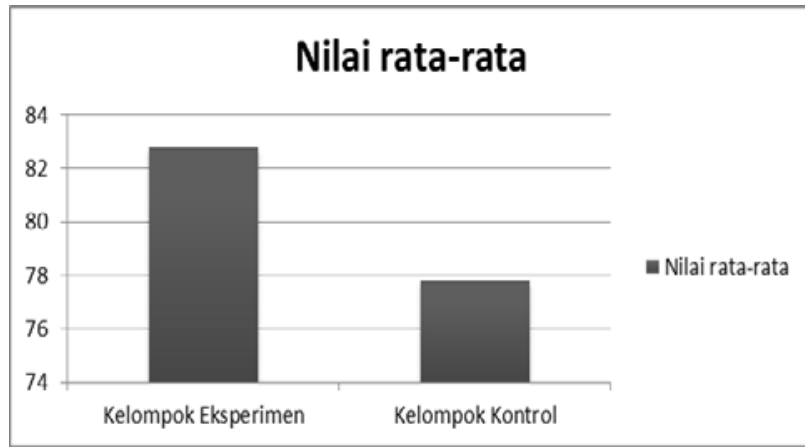

Gambar 2 Histogram perbandingan posttest output nilai studi IPA eksperimen kelas dan kontrol kelas

\section{Deskripsi Bahan-bahan Post-test Kuisioner Rasa Ingin Tahu Peserta yang Dididik}

Post-test pada eksperimen kelas dan kontrol kelas dikasihkan kepada peserta yang dididik dengan jumlah 36 orang. Aktivitas yang dikerjakan yaitu mengisi angket/ kuisioner berupa pernyataan sebanyak 14 butir. Berdasarkan skor rasa ingintahu tahap awal pada eksperimen kelas dan kontrol kelas maka diketahui output yang disajikan di tabel 3.

Tabel 3 Data Deskriptif Post-test Kuisioner

\begin{tabular}{|c|c|c|}
\hline Statistic & Experiment & Control \\
\hline $\mathrm{N} \quad$ jumlah & 36 & 36 \\
\hline \multicolumn{3}{|l|}{ peserta didk) } \\
\hline Jumlah nilai & 1595 & 1345 \\
\hline Rata-rata & 44,3 & 37,4 \\
\hline \multicolumn{3}{|l|}{ Nilai } \\
\hline Nilai Minimal & 28 & 25 \\
\hline Nilai & 55 & 52 \\
\hline \multicolumn{3}{|l|}{ Maksimal } \\
\hline Median & 45,5 & 37,5 \\
\hline St. Deviasi & 6,45 & 6,81 \\
\hline Varians & 41,59 & 46,35 \\
\hline
\end{tabular}

\section{Hasil Interview}

Hasil interview yang diperoleh dari wali kelas V-C selaku pengamat pada saat pengkaji memberi perlakuan pada kelas $\mathrm{V}$-C sebagai eksperimen kelas. Dari hasil interview yang didapat, bahwa pada saat pengkaji memberi perlakuan dengan memakai model PBL pada eksperimen kelas di hasilkan informasi bahwa terdapat kemajuan dalam edukasi IPA dan peningkatan rasa ingintahu peserta yang dididik. Menurut pengamat, karena mapel IPA yang biasanya hanya memakai teori saja, namun dengan adanya model PBL ini peserta yang dididik menjadi terlibat dalam pengalaman yang nyata dengan menerapkannya secara langsung.

Pengamat juga berpendapat bahwa model PBL ini cukup baik dan sangat cocok digunakan pada pengajaran IPA karena peserta yang dididik tidak hanya terpaku atau terpusat pada teori saja tetapi terdapat praktek dalam pengajarannya sampai peserta yang dididik dapat memecahkan masalah berserupa teman kelompoknya. Peserta yang dididik juga menjadi aktif mencari tahu sendiri atau bertanya mengenai bagaimana percobaan-percobaan dalam materi pengajaran IPA dapat berhasil sehingga menyebabkan meningkatnya rasa keingintahuan dari peserta yang dididik itu sendiri.

\section{Uji Hipotesis Pre-test dan Post-test Eksperimen kelas}

Uji t pre-test dan posttes experimen kelas dilakukan agar mengetahui ada tidaknya kontradiksi dalam peningkatan output nilai studi IPA. Percobaan pada hipotesis ini memakai analisis statistik one sample t-test. Akhir dari penyelidikan ini dinyatakan signifikan nilai $p<0,05$. Adapun penjelasan 
singkat uji $\mathrm{t}$ pre-test dan post-test eksperimen kelas ditunjukkan pada tabel 4. Tabel 4 Hasil uji t pre-test dengan post-test eksperimen kelas

\begin{tabular}{lcccccc}
\hline \multicolumn{7}{c}{ One-Sample Test } \\
& \multicolumn{7}{c}{ T } & Df & Sig. (2- tailed) & $\begin{array}{c}\text { Mean } \\
\text { Difference }\end{array}$ & $\begin{array}{c}\text { 95 \% Confidence Interval } \\
\text { of the Difference }\end{array}$ \\
\cline { 2 - 7 } & & & & & Lower & Upper \\
\hline Pre-test & 29,046 & 35 &, 000 & 58,611 & 54,51 & 62,71 \\
Post-test & 42,759 & 35 &, 000 & 82,778 & 78,85 & 86,71 \\
\hline
\end{tabular}

\section{Uji Pre-test dan Post-test Kontrol kelas}

Uji t pre-test dan post-test kontrol kelas dilakukan agar mengetahui ada tidaknya kontradiksi peningkatan dalam nilai output nilai studi IPA. Percobaan pada hipotesis ini menggunkaan analisis statistik one sample $t$ test. Akhir dari penyelidikan ini dinyatakan signifikan nilai $p<0,05$. Adapun penjelasan singkat uji t pre-test dan post-test kontrol kelas ditunjukkan pada tabel 5.

Tabel 5 Hasil uji t pre-test dengan post-test kontrol kelas

\begin{tabular}{|c|c|c|c|c|c|c|}
\hline \multicolumn{7}{|c|}{ One-Sample Test } \\
\hline & \multicolumn{6}{|c|}{ Test Value $=0$} \\
\hline & \multirow[t]{2}{*}{$\mathrm{T}$} & \multirow[t]{2}{*}{$\mathrm{Df}$} & \multirow[t]{2}{*}{ Sig. (2- tailed) } & \multirow[t]{2}{*}{$\begin{array}{c}\text { Mean } \\
\text { Difference }\end{array}$} & \multicolumn{2}{|c|}{$\begin{array}{c}95 \% \text { Confidence Interval } \\
\text { of the Difference }\end{array}$} \\
\hline & & & & & Lower & Upper \\
\hline Pre-test & 36,483 & 35 & ,000 & 63,611 & 60,07 & 67,15 \\
\hline Post-test & 40,830 & 35 & ,000 & 77,778 & 73,91 & 81,64 \\
\hline
\end{tabular}

\section{Uji t Post-test Eksperimen kelas dan Post-test Kontrol kelas}

Analisis bahan bahan memakai independent Sample t-test terhadap post-test eksperimen kelas dan post-test kontrol kelas. Analisis ini digunakan untuk menyakini ada atau tidaknya kontradiksi antara nilai post-test yang signifikan pada eksperimen kelas maupun kontrol kelas. Kesimpulan pengkajian dinyatakan signifikan apabila thitung $>$ ttabel pada taraf signifikansi $5 \%$ dan nilai $p<0,05$. Berikut ini disajikan hasil perhitungan uji independent sample t-test experimet kelas dan kontrol kelas pada tabel 6.
Didapatkan $t$ tabel dari derajat kebebasan $d f=(n 1+n 2)-2=(36+36)-2=70$ pada taraf signifikansi $5 \%$ adalah 1,99 Jadi nilai thitung $>$ ttabel $(2,841>1,99)$ dan nilai signifikansinya kurang dari 0,05 $(p=0,01<0,05)$. Sehingga Ha diterima dan $\mathrm{H} 0$ ditolak. Akhir dari pemaparan di atas bahwa terdapat kontradiksi output nilai studi pada mapel IPA kelas V SD yang lebih baik yaitu peserta yang dididik yang memperoleh pengajaran dengan memakai model PBL (PBL) dibandingkan peserta yang dididik yang memperoleh pengajaran dengan memakai metode yang biasa digunakan pendidik seperti penugasan, dan jawab tanya. 
Tabel 6 Hasil Uji Independent Sample t-test Output studi IPA

\begin{tabular}{ccccc}
\hline Kelompok & $\begin{array}{c}\text { Rata- } \\
\text { rata }\end{array}$ & Thitung & Ttabel & $P$ \\
\hline $\begin{array}{c}\text { Eksperimen } \\
\text { Kontrol }\end{array}$ & $\begin{array}{c}82,7 \\
77,8\end{array}$ & 2,841 & 1,998 & 0,010 \\
\hline
\end{tabular}

\section{Uji $t$ Post-test Kuisioner Rasa Ingintahu Eksperimen Kelas dan Kontrol Kelas}

Analisis bahan bahan memakai independent Sample t-test terhadap post-test eksperimen kelas dan post-test kontrol kelas. Analisis ini digunakan untuk menyakini ada atau meningkatnya antara rasa keingintahuan peserta yang dididik pada eksperimen kelas maupun kontrol kelas. Berikut disajikan hasil perhitungan uji independent Sample ttest eksperimen kelas dan kontrol kelas pada tabel 7 .

Tabel 7 Hasil uji independent sample t-test kuisioner rasa ingin tahu

\begin{tabular}{ccccc}
\hline Kelompok & $\begin{array}{r}\text { Rata- } \\
\text { rata }\end{array}$ & & & \\
& & & \\
\hline Eksperimen & 44,3 & 4,443 & 1,998 & 0,000 \\
Kontrol & 37,3 & & & \\
\hline
\end{tabular}

Dari tabel 7 diketahui t hitung sebesar 4,443 dengan signifikan 0,000. Didapatkan $t$ tabel dari derajat kebebasan $d f=(n 1+n 2)-$ $2=(36+36)-2=70$ pada taraf signifikan 5 $\%$ adalah 1,998 . Jadi nilai $\mathrm{t}$ hitung $>\mathrm{t}$ tabel $(2,841>1,998)$ dan nilai signifikansinya kurang dari 0,05 ( $p=0,000<0,05)$ sehingga $\mathrm{HO}$ ditolak dan Ha diterima. Akhir dari pemaparan di atas bahwa terdapat kontradiksi output rasa keingintahuan cukup tinggi antara peserta yang dididik yang memperoleh pengajaran dengan memakai model PBL dibandingkan peserta yang dididik yang mendapat pengajaran dengan model ekspositori pada mapel IPA kelas V SD.

\section{Pembahasan}

Pengkajian ini dilakukan di SDN Banjarwaru dengan memakai sampel pengkajian adalah kelas V -A dan kelas V -C. Adapun ketentuan kelas $\mathrm{V}$-A sebagai kontrol kelas dan kelas $\mathrm{V}$ -C sebagai eksperimen kelas dengan memakai teknik random sampling. Pada kelas kontrol diberi perlakuan model ekspositori dan pada eksperimen kelas diberi perlakuan model PBL (PBL).

Sebelum dilakukan proses pengajaran, pada eksperimen kelas rata-rata poin pretest yang di hasilkan yakni sebesar 58,6 termasuk kategori sedang. Uji kecakapan awal sebelum dilakukan proses pengajaran dengan t-test mengindikasikan bahwa output awal kedua kelas tidak ada kontradiksi yang signifikan. Berdasarkan hal tersebut mampu diungkapkan bahwa kondisi awal baik pada exsperimen kelas dan kontrol kelas dilaksanakan di kelas $\mathrm{V}$ sebelum dikasihkan perlakuan mempunyai kecakapan awal yang relatif serupa. Hal ini disebabkan sebelum yang dilaksanakan pengkajian dan perlakuan, kedua kelas memakai pengajaran biasa yang dilakukan oleh guru, yaitu ceramah dan jawab tanya atau penugasan.

Hasil pengkajian diperkokoh dengan adanya hasil interview. Hasil interview yang dilakukan pengkaji pada wali kelas V-C selaku pengamat tersebut mengatakan output nilai studi IPA dan rasa keingintahuan peserta yang dididik pada eksperimen kelas dengan memakai model PBL (PBL) terdapat kemajuan dan peningkatan yang ditunjukan melalui aktivitas proses pengajaran yakni peserta yang dididik memiliki kemauan tinggi memecahkan permasalahan yang 
dikasihkan oleh pendidik. Peserta yang dididik mampu bekerja serupa dengan teman di dalam kelompok serta mengindikasikan sikap tanggung jawab dengan menyelesaikan tugas. Ketika mempresentasikan hasil laporan, secara keseluruhan masing- masing peserta yang dididik sudah mampu mengindikasikan rasa percaya diri.

Hal yang dapat mengindikasi model PBL memiliki rerata dan peningkatan cukup tinggi dibandingkan dengan model ekspositori dikarenakan model PBL lebih memberatkan peserta yang dididik untuk tidak pasif dan harus lebih aktif di dalam pengajaran. Meskipun dikasihkan materi yang serupa dengan waktu yang serupa pula, namun di dalam pengajaran model PBL peserta yang dididik dikasihkan suatu kasus atau masalah kemudian melakukan serangkaian experiment, tepatnya peserta yang dididik dilatih untuk mencari tahu sendiri dan menemukan masalah yang ada. Hal tersebut sependapat dengan Arends (Trianto, 2007) yang menyatakan "model PBL merupakan suatu model pengajaran tepatnya peserta yang dididik mengerjakan permasalahan yang otentik dengan tujuan agar dapat mengatur pengetahuan mereka sendiri, dapat membangun kecakapan berpikir ke tingkat yang lebih tinggi, dan membangun keindependenan peserta yang dididik serta peserta yang dididik memiliki kepercayaan terhadap diri sendiri dalam keterampilan". Di dalam proses pengajaran, pendidik hanya bertindak sebagai fasilitator, sedangkan peserta yang dididik lebih berperan aktif sehingga peserta yang dididik akan merasa memiliki tanggung jawab untuk mencarai sendiri informasi yang dibutuhkannya melalui arahan dan bimbingan pendidik untuk memecahkan suatu permasalahan.
Pada kontrol kelas peserta yang dididik telah memiliki potensi output nilai studi edukasi IPA, namun belum difasilitasi oleh pendidik. Sedangkan pada capaian hasil pencapaian post-test pada kontrol kelas persentase yang di hasilkan lebih rendah di bandingnkan eksperimen kelas, pada beberapa indikator persentase mengalami penurunan dari pre-test. PBL (PBL) adalah suatu model pestudian yang menuntut peseta didik untuk berpikir kritis, memecahkan masalah, dapat studi independen, dan menuntut keterampilan berpatisipasi dalam kerjasama. Cara dalam memecahkan persoalan dilakukan secara bekerja sama dan disesuaikan dengan kenyataan yang ada. Proses PBL di SD dapat melatih dalam meningkatkan nilai studi edukasi IPA dan mengembangkan rasa keingintahuan peserta yang dididik, khususnya pada kelas yang lebih atas yaitu kelas 4, 5, dan 6. Hal ini sesuai dengan karakteristik anak usia SD pada kelas atas yaitu peserta yang dididik kelas 4,5, dan 6 sudah mulai independen dan sudah ada rasa tangung jawab terhadap dirinya sendiri.

Berdasarkan pemamparan di atas dapat dinyatakan bahwa terdapat perbedaan yang signifikan penerapan model PBL terhadap output nilai studi IPA dan rasa ingintahuan peserta yang dididik. Perbedaan yang di hasilkan signifikan karena hasil signifikansi $0,010<0,05$ pada pengukuran output nilai studi IPA dan pada rasa ingintahuan terdapat perbedaan output signifikan karena hasil signifikansi $0,000<0,05$ setelah dilakukan proses pengajaran.

\section{KESIMPULAN DAN IMPLIKASI}

\section{Kesimpulan}

Berdasarkan hasil pengkajian dan pembahasan, maka dapat disimpulkan 
bahwa terdapat pengaruh positif signifikan pada model Problem Based Learning terhadap rasa ingintahu dan output nilai studi IPA sebagai berikut.

1. Berdasarkan output analisis bahan bahan independent sample t-test denga taraf signifikan $5 \%$ output studi IPA di hasilkan yaitu $0,010<0,05$. Hal ini menyatakan model Problem Based Learning berpengaruh positif terhadap output studi IPA.

2. Output analisis bahan bahan independet sample t-test dengan taraf signifikan $5 \%$ rasa ingintahu peserta yang dididik di hasilkan yaitu $0,000<0,05$. Hal ini menyatakan model Problem Based Learning berpengaruh positif terhadap rasa keingintahuan peserta yang dididik.

3. Berdasarkan pernyataan tersebut maka dinyatakan bahwa pengajaran dengan model Problem Based Learning (PBL) lebih efektif dalam output studi IPA dan peningkatan rasa keingintahuan peserta yang dididik daripada pengajaran biasa yang diterapkan oleh pendidik yaitu melalui pendekatan konvensional.

\section{Implikasi}

Guru sebaiknya menerapkan model Problem Based Learning (PBL) dalam aktivitas pengajaran di kelas yang disesuaikan dengan kelas yang lebih atas yaitu kelas 4, 5, dan 6 serta materi yang akan di pelajari, karena model pengajaran ini terbukti memberikan dampak terhadap output studi dan rasa ingintahu peserta yang dididik.

\section{DAFTAR PUSTAKA}

Amir, M. T. (2010). Inovasi Edukasi Melalui Problem Based Learning. Jakarta: Kencana Prenada Media Grup.

Dasim, B. (2012). Perencanaan Pengajaran Berbasis Karakter. Bandung: Widya Aksara Press.

Mulyana, H. (2010). “Metodologi Pengajaran Sains di Sekolah Dasar". Tasikmalaya: UPI KampusTasikmalaya.

Sudjana, N. (2009). Dasar-dasar Proses Pengajaran Mengajar. Bandung: Sinar Baru.

Sugiyono. (2015). Metode Pengkajian Kuantitatif, Kualitatif dan R\&D. Bandung : Alfabeta.

Trianto. (2012). Model Pengajaran Terpadu (Konsep, Strategi, dan Implementasinya dalam Kurikulum Satuan Tingkat Edukasi. Jakarta : Bumi Aksara.

Trianto. (2012). Mendesain Model Pengajaran Inovatif - Progresif. Jakarta : Kencana Prenada Media Group.

Wulandari, E., Budi, S. H., \& Suryandari, K.C. (2013). Penerapan Model PBL (Problem Based Learning) pada Pembelajaan IPA Siswa Kelas V SD. Kalam Cendekia PGSD Kebumen, 1(1). 